\title{
Chlorophyllase of Tobacco Plants I. Preparation and Properties of Water Soluble Enzyme
}

\author{
by Seki Shimizu* and Einosuke Tamaki*
}

Received September 26, 1962

When tobacco plants reach the mature state, farmers put them into the state of nitrogen starvation, cutting the supply of manure. In this stage, the leaf turns yellow, and there seems to be at least two possible ways to advance this change: 1 . changes in nitrogenous compounds, especially in proteid components of chloroplasts, 2. destruction of chlorophylls.

We studied the biological destruction of chlorophylls. Willstätter and Stoli ${ }^{1)}$ showed that chlorophylls could be hydrolyzed in aqueous acetone solution by the dried powder of leaves free from the pigments. This reaction was enzymic and this enzyme was named "chlorophyllase". This enzyme activity has been observed in various plants ${ }^{2-7)}$ and many attempts have been made without success to isolate the enzyme in a soluble state ${ }^{1,2)}$. However, recently Ardao and Vennesland ${ }^{8)}$ found that the soluble chlorophyll-lipoprotein complex obtained from spinach chloroplasts by digitonin treatment had chlorophyllase activity, and Holden ${ }^{9)}$ succeeded in preparing soluble chlorophyllase from sugar beet (Beta vulgaris var. saccharifera), but she failed to get the enzyme in a soluble state from tobacco leaves.

We succeeded to obtain chloropoyllase in a soluble state from tobacco leaves by a simpler method than the Holden's. This paper deals with the preparation of soluble chlorophyllase from tobacco leaves and some properties of the enzyme.

\section{Materials and Methods}

Plant materials:

Tobacco leaves (Nicotiana tabacum var. Bright Yellow) were obtained from Utsunomiya Tobacco Experiment Station.

Preparation of chloroplasts:

As chlorophyllase locates in chloroplasts ${ }^{4}$, we intended to prepare the enzyme from chloroplasts: Laminae of tobacco leaves were homogenized with twice weight of ice-cold $0.35 \mathrm{M} \mathrm{NaCl}$ for $30 \mathrm{sec}$. The homogenate was squeezed through three folds of gauze and centrifuged at $500 \times g$ for $3 \mathrm{~min}$. From the resultant supernatant, chloroplasts were sedimented by centrifugation at $1,500 \times g$ for $12 \mathrm{~min}$. The chloroplasts were suspended in $0.35 \mathrm{M} \mathrm{NaCl}$ and recentrifuged at $1,500 \times g$ for $12 \mathrm{~min}$. The washing procedure was repeated twice.

Extraction of chlorophyllase from chloroplasts:

Autolysis and digestion with lipase and proteolytic enzymes have been used for bringing into solution several enzymes associated with cell nuclei and mitochondria, while treatment with detergent has enabled some separation of component from chloroplasts $^{10-13)}$. These methods have limited application and are more or less undesirable for enzyme purification.

Morton $^{14-16)}$ has shown that the controlled use of $n$-butanol enables to make ready solution of a wide range of enzymes from insoluble particles into distilled water or

\footnotetext{
* Central Research Institute of Japan Monopoly Corporation, Shinagawa, Tokyo, Japan.
} 
dilute buffers by removal of lipid and other materials from cell structure.

Sissakyan and his co-workers ${ }^{17-19)}$ applied the Morton's method to plant cell. These Russian researchers extracted the proteid component from sugar beet leucoplasts and chloroplasts. We followed the Morton's method with a little modification: Fifteen grams of chloroplasts were suspended in $60 \mathrm{ml}$ of water $(\mathrm{pH} \mathrm{9.0,} \mathrm{adjusted}$ with $\mathrm{NaOH}$ ) or in the same volume of $1 \% \mathrm{NaCl}$ solution. Slow addition of $120 \mathrm{ml}$ of $n$-butanol with vigorous mechanical stirring at room temperature formed an emulsion. The emulsion was rapidly stirred and warmed to $37^{\circ}$ for $10 \mathrm{~min}$. by immersion of the vessel in a water-bath held at $40^{\circ}$. By centrifugation $(1,000 \times g$ for $5 \mathrm{~min}$.), the materials were separated into three distinct layers; a clear yellow aqueous zone over$l_{\text {aid }}$ by light particles, and a surface layer of excess $n$-butanol containing dissolved chlorophylls. The upper layer was readily removed by suction. The lower aqueous phase was removed by suction through a narrow glass tube and filtered. The filtrate was dialyzed against distilled water for $24 \mathrm{hrs}$., to remove the $n$-butanol contained in it.

\section{Method of determining chlorophyllase activity:}

Many methods have been proposed for the determination of chlorophyllase activity. They might be divided into three groups. The first group was that described by Willstätter and Stoll ${ }^{1)}$ and used by Mayer ${ }^{2)}$ and Peterson and Mackinney ${ }^{3)}$. The pigment is extracted first into ether and then into alkali. The second method used by Weast and Mackinney ${ }^{5)}$, Ardao and Vennesland $^{8)}$ and recently by Holden ${ }^{9}$ is based on the insolubility of chlorophyllides in light petroleum. The chromatographic method described by Sironval $^{20)}$ and used by Gage and Aronoff ${ }^{7)}$ is the third method and seems to be most accurate. This method was used in the present investigation. For the substrate of the enzyme the acetone extract of tobacco leaves was used. The leaves were ground in $80 \%$ aqueous acetone $(3 \mathrm{ml} / \mathrm{g}$, of leaf), the extract was filtered and stored at $0^{\circ}$ for several days. Before use, it was necessary to filter the acetone extract to remove carotenoids and others which had precipitated. The content of chlorophyll was determined by the method of Arnon ${ }^{21}$.

One $\mathrm{m} l$ of protein solution was incubated with $20 \mathrm{ml}$ of chlorophyll solution (approximately 100 $\mathrm{mg} / \mathrm{l})$ and $4 \mathrm{~m} l$ of $0.02 \mathrm{M}$ Na-citrate. The flask

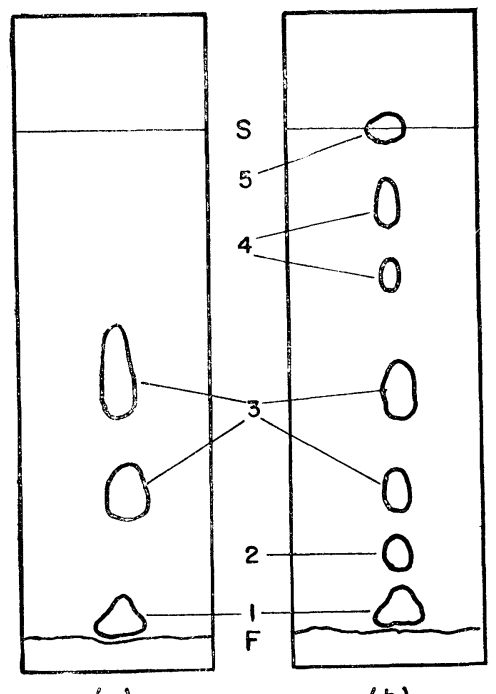

(a)

(b)

Fig. 1. Paper chromatograms of the reaction mixture, (a), at $0 \mathrm{~min}$. and (b), at $60 \mathrm{~min}$.

1, carotenoides; 2, pheophytines;

3 , chlorophylls; 4 , pheophorbides;

5 , chlorophyllides. was sealed, covered with aluminium foil to exclude light and agitated occasionally at room temperature. One $\mathrm{m} l$ of this reaction mixture was transferred to Whatman No. 1 paper $(15 \times 40 \mathrm{~cm})$ and chromatographed in the dark at $20^{\circ}$, using the descending method with a solvent system of benzene-petroleum ether-acetone (10:2.5:2), in an atmosphere of petroleum ether. After development, bands corresponding to chlorophylls $\mathrm{a}$ and $\mathrm{b}$ were cut off and eluted quantitatively with $80 \%$ acetone.

The activity of enzyme was expressed as a perecentage of the broken chlorophylls 
by $1 \mathrm{~g}$ of protein in $60 \mathrm{~min}$.

Determination of protein concentration:

Protein concentration was determined according to the method of Lowry et al. ${ }^{22)}$, using casein as a reference standard.

\section{Results}

Partial purification of enzyme:

The enzyme was precipitated with acetone and ammonium sulphate. The results of precipitation are shown in Table 1. The precipitation with ammonium sulphate gave better result. Partially purified preparation had low amylase and polyphenol oxidase activity.

\section{Effect of extraction medium:}

Protein was extracted from chloroplasts with two kinds of solvents; water adjusted to $\mathrm{pH} 9.0$ with $\mathrm{NaOH}$ and $1 \%$ aqueous solution of $\mathrm{NaCl}$. The amount of protein extracted with these solvents and the enzymic activities of the resultant solutions are shown in Table 2. There was no difference between the amounts of extracted protein in both solvents, but stronger enzymic activity was obtained with $1 \% \mathrm{NaCl}$ solution. In this paper, we used $1 \% \mathrm{NaCl}$ for all the experiments as extraction medium, unless otherwise mentioned.

Table 1. Partial purification of enzyme.

\begin{tabular}{|c|c|c|c|}
\hline Fraction & $\begin{array}{l}\% \text { of } \\
\text { recovery }\end{array}$ & Total unit & $\begin{array}{l}\text { Activity per } g \\
\text { of protein }\end{array}$ \\
\hline $1 \% \mathrm{NaCl}$ extract & 100 & 2,091 & 8,500 \\
\hline Acetone ppt. (0-67\%) & 54 & 345 & 2,600 \\
\hline$(67-87 \%)$ & 1.1 & 36 & 17,100 \\
\hline$\left(\mathrm{NH}_{4}\right)_{2} \mathrm{SO}_{4}$ ppt. (0.4 sat.) & 15.8 & 152 & 7,100 \\
\hline (0.6 sat.) & 19.7 & 117 & 4,600 \\
\hline (0.9 sat.) & 26.3 & 1,061 & 29,850 \\
\hline
\end{tabular}

Table 2. Extraction of enzyme.

\begin{tabular}{c|c|c}
\hline Extract & $\begin{array}{c}\text { Extracted protein from } \\
40 \mathrm{~g} \text { of } \\
\text { chloroplast }(\mathrm{mg})\end{array}$ & $\begin{array}{c}\text { Activity per } \mathrm{g} \\
\text { of protein }\end{array}$ \\
\hline $1 \% \mathrm{NaCl}$ extract & 62.4 & 7,650 \\
$\mathrm{H}_{2} \mathrm{O}$ extract & 62.0 & 5,560 \\
\hline
\end{tabular}

Properties of enzyme:

(1) Effect of pH. Fig. 2 presents the effect of $\mathrm{pH}$ on the activity of the partial purified enzyme. McIlvaine's $\mathrm{Na}_{2} \mathrm{HPO}_{4}$-citric acid buffer was used for the whole range. The optimum $\mathrm{pH}$ lay between 7.0 and 7.5.

(2) Effect of substrate concentration. Fig. 3 shows how the concentration of substrate affects the enzyme activity. Over $0.5 \times 10^{-4} \mathrm{M}$ (concentration of chromatographically pure chlorophyll a), the enzyme activity was rather reduced.

(3) Effect of time. As shown in Fig. 4, the chlorophyllase activity increased 


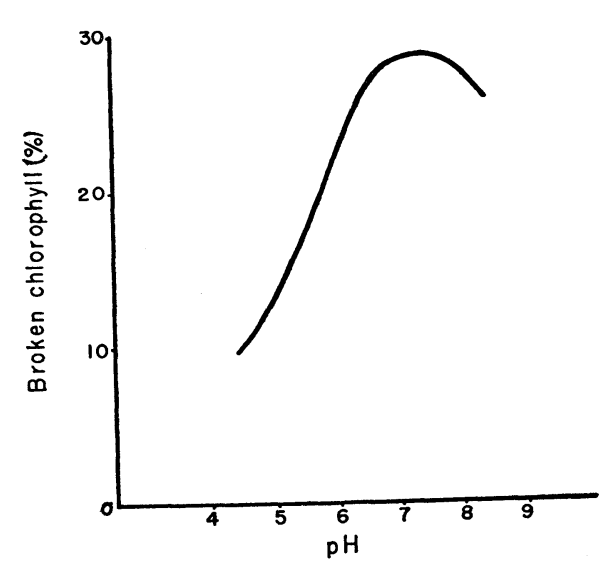

Fig. 2. Effect of $\mathrm{pH}$ on the enzymic activity.

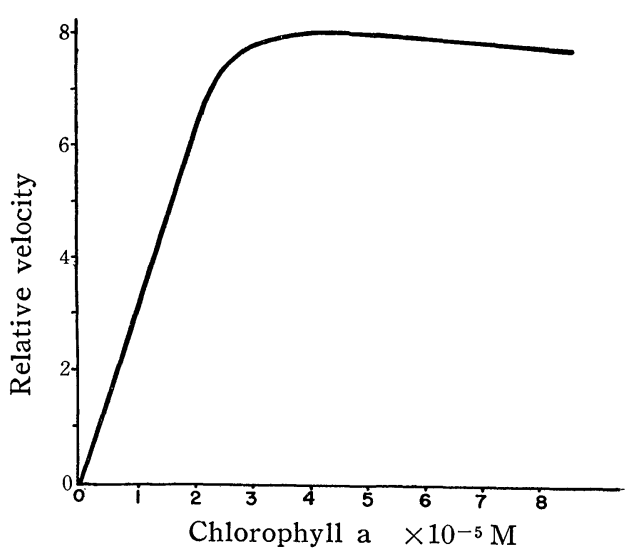

Fig. 3. Effect of substrate concentration: Relative velocity is measured from decrease of optical density at $663 \mathrm{~m} \mu$ for 20 minutes.

linearly during the first 30 minutes and then was suppressed in around 100 minutes.

(4) Seasonal changes of chlorophyllase activity and chlorophyll content. Leaves in the stalk position 19th from the bottom of the plants were sampled for enzyme activity and chlorophyll content determination. The sampling was started on the 30th day after germination and discontinued on the 145th day. During this period, 9 samplings were performed.

As shown in Fig. 5, the enzyme activity (curve I) reached maximum on the 56th day, and the maximum chlorophyll content (curve II) was found on the 91st day. There was a clear parallel relationship between the two curves. This finding may suggest that the biosynthesis of chlorophyll is closely related to chlorophyllase activity.

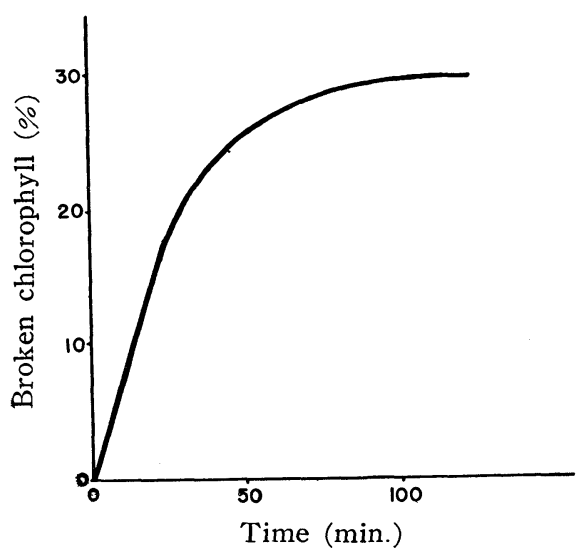

Fig. 4. Enzyme stability.

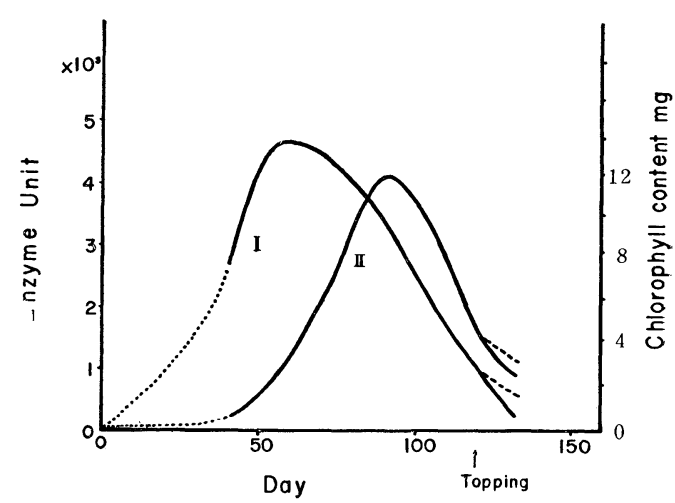

Fig. 5. Seasonal changes of enzyme activity and chlorophyll content: (I), enzyme unit per $1 \mathrm{~g}$ of protein; (II), chlorophyll content per $1 \mathrm{~g}$ of chloroplasts.

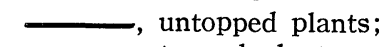




\section{Discussion}

There have been only a few studies on chlorophyllase and this might be, in part, due to the difficulty to isolate the enzyme in a water soluble form. This property is resulted from the fact that an active protein of the enzyme may be linked with lipids. Ardao and Vennesland ${ }^{8)}$ suggested that the chlorophyllase of mature spinach leaf might be present in a chlorophyll-lipoprotein complex. Holden ${ }^{9}$ also said that the linkage between the enzyme protein and lipids, either physically or chemically, might be responsible for the insolubility of chlorophyllase. In our research, we used $n$-butanol which removed the lipids and liberated the active protein into aqueous solution. The liberated protein was free from chlorophyll components and was slightly yellow.

The first step on the enzymic breakdown of chlorophyll in vivo has been thought to be removal of the phytol chain to yield water soluble chlorophyllide which then can undergo further degradations ${ }^{6,8,9}$. Then at the beginning of this study, the increase in chlorophyllase activity had been predicted to be a main cause of the yellowing of mature tobacco leaves. However, the present results have disproved this assumption with tobacco plants, and a similar result was reported with chlorosis in a soybean mutant ${ }^{7)}$. The decrease of the chlorophyll content in the mature leaf seemed to be caused by the decreasing activity of the enzyme in synthetic way and not by the increasing enzyme activity towards the opposite direction.

On the role of chlorophyllase in the synthesis of chlorophylls in higher plants, there have been few clear-cut demonstrations ${ }^{8,23,24}$, except that of Willstätter and Stoll ${ }^{11}$.

Younger tobacco leaves being low in the chlorophyll content had a stronger chlorophyllase activity than old ones. Sudina ${ }^{24}$ ) also observed an increase of the enzyme activity before chlorophyll formation took place during greening of etiolated hemp leaves. In the present work, the acetone extract of tobacco leaf was used as substrate of chlorophyllase. The young leaf extract, after idcubation with chlorophyllase, gave a higher chlorophyll content than the original extract. On the other hand, the same treatment of the mature leaf extract decreased the chlorophyll content. It was reported that the content of phytol of young maize leaf was higher than older one ${ }^{25)}$, and that after a short time illumination an etiolated hemp seedling contained much chlorophyllide ${ }^{24}$. If these two observations are true for tobacco plants, with this high content of phytol and chlorophyllide in the young tobacco leaf extract, chlorophyllase could act in a reverse way to synthesize chlorophyll. On this point, however, a further study is required to give any definite conclusion, and such a study is now in progress.

\section{Summary}

1. Water soluble chlorophyllase preparation was made from chloroplasts of tobacco plants, using $n$-butanol and aqueous solution of scdium chloride as the solvents.

2. Some properties of the enzyme were studied.

3. Seasonal changes of enzyme activity and chlorophyll content were studied. Chlorophyllase activity varied in advance of the variation of chlorophyll content.

4. Possible participation of chlorophyllase in the biosynthesis of chlorophyll was. discussed. 
We wish to express our thanks to Miss K. Kodaira and Miss H. Fukushima of our laboratory for their technical assistance.

\section{Reference}

1) Willstätter, R., and Stoll, A., Liebigs Ann. 378: 18 (1910). Quoted in "Investigations on Chlorophyll", Science Press, England (1928). 2) Mayer, H., Planta 11: 294 (1930). 3) Peterson, P. D., and Mackinney, H. H., Phytopathology 28: 329 (1938). 4) Krossing, G., Biochem. Z. 305: 359 (1940). 5) Weast, C. A., and Mackinney, G., J. Biol. Chem. 133: 551 (1940). 6) Noack, K., Biochem. Z. 316: 166 (1943). 7) Gage, R.S., and Aronoff, S., Plant Physiol. 31: 477 (1956). $\quad$ 8) Ardao, C., and Vennesland, B., Plant Physiol. 35: 368 (1960). 9) Holden, M., Biochem. J. 78: 359 (1961). 10) McClendon, J. H., and Blinks, L.R., Nature 170: 577 (1952). 11) Ke, B., and Clendenning, K. A., Biochem. Biophys. Acta 19: 74 (1956). 12) Whatley, F. R., Allen, M. B., and Arnon, D. I., Biochim. Biophys. Acta 32: 32 (1959). 13) Nieman, R. H., Nakamura, H., and Vennesland, B., Plant Physiol. 34: 262 (1959). 14) Morton, R. K., Nature 166: 1092 (1950). 15) __ Biochem. J. 55: 786 and 795 (1953). 16) —_, ibid. 61: 232 and 240 (1955). 17) Sissakyan, N. M., Besinger, E. N., and Kuvaeva, E. B., Doklady Akad. Nauk U.S.S.R. 87: 113 (1952). 18) _—, Biokhimiya 17: 626 (1952). 19) Sissakyan, N. M., and Melik-Sarkisyan, Biokhimiya 21: 329 (1956). 20) Sironval, C., Physiol. Plant. 7: 523 (1954). 21) Arnon, D. I., Plant Physiol. 24: 1 (1949). 22) Lowry, O. H., Rosenbrough, N. J., Farr, A. L., and Randall, R.T., J. Biol. Chem. 193:265 (1951). 23) Wolff, J. B., and Price, L., Plant Physiol. 31: xxxi (1956). 24) Sudina, E. G., "Problems of Photosynthesis", Publishing House of U.S.S.R. Academy of Science, 204-213 (1959). 25) Fischer, F. G., and Bohn, H., Liebigs Ann.: 611: 224 (1958).

\section{摘 要}

清 水 碩・玉置英之助：タバコのクロロフィラーゼ I. 水溶性酵素の調製とその性質

タバコの葉が成熟期に達したとき，窒素肥料をあたえないで窒素飢餓の状態に物かれると，葉は黄色に なってゆく，このときどのような生理的な変化が括こって，葉緑素が分解してゆくかを，クロロフィラー ぜ活性の変化を中心に観察した。この酵素はクロロフィルをフィトールとクロロフィリッドとに加水分解 する，後者は水溶性であるために，以後の変化を受けやすくなるのだといわれてきた。 クロロフィラーゼ は，これまで水溶性の状態で得ることが困難であるとされていたが，われわれは $n$-ブタノールをるちい て，タバコの葉緑体から活性の大きな酵素を得ることができた，そこで一定の着位の葉について，この酔 素の活性の変化と，それと同時に葉緑素の量の変化とを，いろいろな時期に調べた。 その結果，若い葉で の酵素活性は大きいが，古くなるにつれて低下すること，これに比例して葉緑素の量の增減することがわ かった。 したがって，タバコに括いてはクロロフィラーゼはむしろ葉緑素の生成に関係し， これを分解 し，葉を黄変させることに大きな役割を果たしているようには思われない。（日本専売公社中央研洗所） 